\title{
Metallic-diamond tools with increased abrasive wear resistance for grinding industrial floor systems
}

\author{
Narzędzia metaliczno-diamentowe o podwyższonej odporności na zużycie \\ ścierne do szlifowania przemysłowych systemów podłogowych
}

\section{ELŻBIETA CYGAN-BĄCZEK PIOTR WYŻGA*}

DOI: https://doi.org/10.17814/mechanik.2021.3.6

\begin{abstract}
This paper presents results of research on the physical, mechanical, and tribological properties of materials constituting the matrix in sintered metallic-diamond tools. The ground powders based on the Fe-Mn-Cu-Sn-C system were modified with particles of the ceramic phase: $\mathrm{SiC}, \mathrm{Al}_{2} \mathrm{O}_{3}$ and consolidated using the SPS (spark plasma sintering) method to a relative density of over $98 \%$ at $850 \div 950^{\circ} \mathrm{C}$, at a pressure of $35 \mathrm{MPa}$ and time $10 \mathrm{~min}$. In order to assess the performance of the test materials, the metallic-diamond segments were made. The segments were tested for resistance to abrasive wear in the process of grinding concrete surfaces. It has been shown that it is possible to obtain materials with enhanced mechanical and tribological properties for sintered metallic-diamond tools intended for grinding industrial floor systems.
\end{abstract}

KEYWORDS: matrix, diamond, metallic-diamond tools, SPS, abrasive wear resistance

Przedstawiono wyniki badań właściwości fizycznych, mechanicznych i tribologicznych materiałów stanowiących osnowę w spiekanych narzędziach metaliczno-diamentowych. Mielone proszki na bazie mieszanki Fe-Mn-Cu-Sn-C modyfikowano cząstkami fazy ceramicznej: $\mathrm{SiC}, \mathrm{Al}_{2} \mathrm{O}_{3}$ i konsolidowano metodą SPS (spark plasma sintering) do gęstości względnej powyżej $98 \%$ w temperaturze $850 \div 950^{\circ} \mathrm{C}$, pod ciśnieniem $35 \mathrm{MPa}$ i w czasie $10 \mathrm{~min}$. W celu oceny właściwości użytkowych badanych materiałów wykonano segmenty metaliczno-diamentowe, które poddano badaniom odporności na zużycie ścierne w procesie szlifowania powierzchni betonowych. Wykazano, że możliwe jest otrzymanie materiałów o podwyższonych właściwościach mechanicznych i tribologicznych nadających się na spiekane narzędzia metaliczno-diamentowe przeznaczone do szlifowania przemysłowych systemów podłogowych.

SŁOWA KLUCZOWE: osnowa, diament, narzędzia metaliczno-diamentowe, spiekanie SPS, odporność na zużycie ścierne

\section{Wprowadzenie}

$\mathrm{Na}$ przestrzeni ostatnich lat widoczny jest systematyczny rozwój usług szlifowania posadzek betonowych i kamiennych. Głównym powodem tego wzrostu było pojawienie się nowych technik ułatwiających obróbkę betonu/kamienia dzięki importowi nowoczesnych maszyn. Urządzenia do obróbki z wykorzystaniem technologii diamentowej, sprowadzane głównie z Włoch, Niemiec i Belgii, a od 8 lat także krajowej produkcji, umożliwiły zakładom rozszerzenie oferty i zaspokojenie rosnących potrzeb rozwijającego się rynku budowlanego.

Pojęcie „posadzki przemysłowe” obejmuje nawierzchnie wewnętrzne w obiektach przemysłowych, magazynach czy centrach handlowych. Najbardziej popularne są posadzki betonowe. Warstwę wierzchnią posadzek przemysłowych stanowią: zatarta powierzchnia, najczęściej dodatkowo utwardzona i związana z betonowym podłożem (podkładem), nawierzchnia żywiczna, mineralna (np. lastrico), płytki ceramiczne i kamień.

Szlifowane i polerowane posadzki betonowe mają szerokie zastosowanie. Doskonale się sprawdzają w pomieszczeniach gospodarczych, przemysłowych czy biurowych. Beton staje się również inspiracją dla projektantów i architektów wnętrz. Kiedyś betonowe posadzki wylewano głównie w halach fabrycznych i magazynach, natomiast w domach stosowano je czasem w piwnicach i garażach, gdzie niewykończona podłoga dobrze spełniała swoje zadanie. Obecnie betonowe posadzki zastępują parkiety, panele laminowane oraz płytki ceramiczne w kuchniach czy łazienkach.

Jedną z podstawowych usług regularnie świadczonych przez firmy zajmujące się przygotowaniem powierzchni jest przywracanie starym posadzkom betonowym pierwotnego wyglądu. Służą do tego narzędzia metaliczno-diamentowe, których wybór zależy od własności obrabianego materiału (np. twardości, gęstości, składu mineralogicznego, własności ściernych) oraz warunków obróbki (wydajności szlifowania, wydajności systemu chłodzenia, stanu technicznego maszyny). Do produkcji narzędzi metaliczno-diamentowych do szlifowania posadzek betonowych powszechnie stosuje się kobalt oraz jego stopy, Co+20\%WC, Fe-Cu-Co-WC.

Głównym wytwórcą proszków kobaltu przeznaczonych do produkcji narzędzi diamentowych jest

\footnotetext{
* Dr inż. Elżbieta Cygan-Bączek, elzbieta.baczek@kit.lukasiewicz.gov.pl, https://orcid.org/0000-0003-2139-761X - Sieć Badawcza Łukasiewicz - Krakowski Instytut Technologiczny, Kraków, Polska

Dr inż. Piotr Wyżga, piotr.wyzga@kit.lukasiewicz.gov.pl, https://orcid.org/0000-0003-3103-5292 - Sieć Badawcza Łukasiewicz - Krakowski Instytut Technologiczny, Kraków, Polska
} 
koncern Umicore. Oferuje on szeroką gamę produktów na bazie tego pierwiastka. Jednak z uwagi na jego wysoką i niestabilną cenę oraz szkodliwy wpływ na zdrowie rozpoczęto badania nad opracowaniem tańszych, stopowych proszków metali, które mogłyby stanowić materiały alternatywne $\mathrm{w}$ produkcji narzędzi metaliczno-diamentowych. Opracowano stopowe proszki na bazie miedzi i żelaza noszące handlowe nazwy Cobalite (produkcji Umicore) [1], Next i Keen (produkcji Eurotungstene, obecnie należącej do firmy Umicore) [2,3]. Badania materiałów wytworzonych z wykorzystaniem komercyjnych proszków Co-Fe-Cu były przedmiotem licznych publikacji o charakterze informacyjnym lub naukowym [4-9].

Kolejnym krokiem w inżynierii spieków przeznaczonych na osnowy narzędzi metaliczno-diamentowych było całkowite wyeliminowanie $\mathrm{z}$ ich składu chemicznego kobaltu, co wiązało się ze zwiększeniem zawartości żelaza. Prace badawcze $\mathrm{w}$ tym kierunku podjęto m.in. w Akademii Górniczo-Hutniczej im. St. Staszica w Krakowie we współpracy z firmą H.C. Starck [10-16]. Badania nad materiałami bez udziału kobaltu były również prowadzone przez S. Spriano i in. [17], S. Hamar-Thibault i C.H. Alliberta [18], jak również Ching-Shan Lin i in. [19] oraz Luciano José de Oliveirę z zespołem [20]. Opracowane materiały mogą być rozwiązaniem alternatywnym wobec materiałów komercyjnych (Co, Co-20\%WC).

Ze względu jednak na oddziaływanie obrabianego materiału na narzędzie podczas obróbki - wywołujące naprężenia i odkształcenia warstw osnowy w pobliżu powierzchni roboczej segmentów - późniejsze badania skierowano na opracowanie materiału, który ulegałby silnemu umocnieniu $\mathrm{w}$ trakcie pracy narzędzia $[21,22]$. Badania trwałości eksploatacyjnej narzędzi metaliczno-diamentowych na bazie opracowanego materiału osnowy z układu Fe-Mn-Cu-Sn-C wskazały na ich potencjalne zastosowanie $\mathrm{w}$ szlifowaniu powierzchni z materiałów sypkich oraz luźnego betonu typu C12/15-C20/25, do czego są przeznaczone narzędzia o twardej osnowie $(\sim 100 \div 110$ HRB). Dalszy rozwój tych materiałów w kierunku podwyższenia ich odporności na zużycie ścierne poprzez kształtowanie struktury i własności użytkowych materiału osnowy w narzędziowych spiekach metaliczno-diamentowych stanowił istotę realizowanych badań i wynikał z konieczności zapewnienia im odpowiednich właściwości, by zapobiec przedwczesnemu zużyciu narzędzi podczas obróbki materiałów.

\section{Materiał do badań i metodyka}

Do sporządzenia mieszanek wykorzystano proszki: - Fe-Mn-Cu-Sn-C otrzymane z elementarnych proszków żelaza redukowanego węglem $\mathrm{z}$ gatunku NC100.24 firmy Höganäs, brązu cynowego z gatunku NAM40-80/20 firmy NEO CHIMIE, żelazomanganu wysokowęglowego z gatunku XH1210 i niskowęglowego z gatunku XH1218 firmy ESAB,

- SiC seria F320 firmy Washington Mills Electro Minerals,

- $\mathrm{Al}_{2} \mathrm{O}_{3}$ seria EF-320 firmy Stanchem.
Metodą analizy sitowej - zgodnie z normą - wyznaczono średnią wielkość cząstek proszków (rys.1a). W postaci krzywych skumulowanych przedstawiono procentowe udziały poszczególnych frakcji ziarnowych (rys. $1 b$ ). W celu określenia kształtu oraz potwierdzenia wielkości cząstek proszki poddano badaniom morfologii z użyciem skaningowego mikroskopu elektronowego. Obrazy mikroskopowe poszczególnych proszków przedstawiono na rys. 2.

Z wykorzystaniem młynka kulowego wykonano mieszanki o następującym składzie:

- Fe-Mn-Cu-Sn-C (Baza),

- Fe-Mn-Cu-Sn-C (Baza) z dodatkiem 10\% fazy SiC, - Fe-Mn-Cu-Sn-C (Baza) z dodatkiem $10 \%$ fazy $\mathrm{Al}_{2} \mathrm{O}_{3}$.
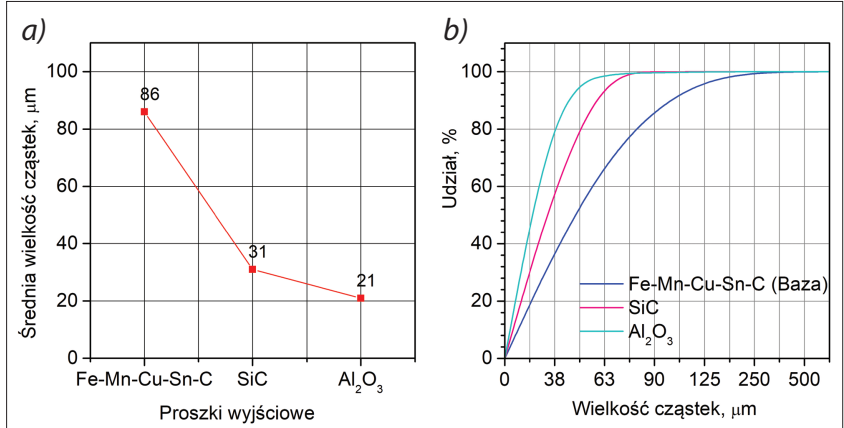

Fig. 1. The starting powders: $a$ ) mean particle size, and $b$ ) cumulative particle size distribution curves

Rys. 1. Proszki wyjściowe: a) średnia wielkość cząstek oraz b) krzywe skumulowane rozkładów wielkości cząstek

a)

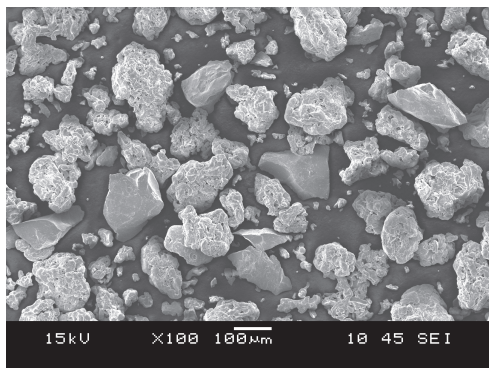

b)

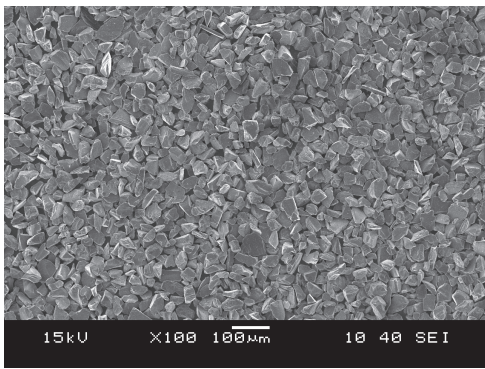

c)

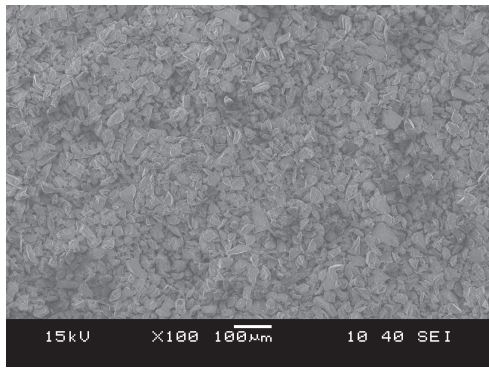

Fig. 2. Powders used for tests: $a$ ) base mixture Fe-Mn-Cu-Sn-C, b) SiC, c) $\mathrm{Al}_{2} \mathrm{O}_{3}$

Rys. 2. Proszki użyte do badań: a) mieszanka bazowa Fe-Mn-Cu-Sn-C, b) $\mathrm{SiC}, \mathrm{c}) \mathrm{Al}_{2} \mathrm{O}_{3}$ 
Przygotowane mieszanki mielono przez 8 godz. w atmosferze powietrza, w pojemniku wypełnionym w 50\% objętości kulami o średnicy $\varnothing 12 \mathrm{~mm}$, wykonanymi ze stali 100Cr6. Stosunek masy kul do masy mielonego proszku wynosił 10:1. Prędkość obrotowa bębna wynosiła około 70\% prędkości krytycznej.

Po procesie homogenizacji mieszanki konsolidowano metodą SPS (spark plasma sintering); zastosowano urządzenie HPD5 firmy FCT Systeme GmBH. Temperatura spiekania wynosiła $850 \div 950^{\circ} \mathrm{C}$, ciśnienie: $35 \mathrm{MPa}$, prędkość grzania: $100^{\circ} / \mathrm{min}$, a czas przetrzymania: $10 \mathrm{~min}$. Spiekanie prowadzono w atmosferze argonu.

Otrzymane spieki poddano badaniom gęstości metodą ważenia w powietrzu i wodzie oraz pomiarom twardości metodą Rockwella, z użyciem skali B. Materiały o najkorzystniejszych właściwościach fizycznych i mechanicznych przekazano do badań odporności na zużycie ścierne w obecności trzech ciał - metodą Micro Wear Test (MWT) opracowaną przez firmę Struers [23, 24], oraz dwóch ciał - z zastosowaniem procedury opracowanej w AGH [24].

Do oceny przydatności opracowanych materiałów do obróbki powierzchni betonowych wykonano segmenty metaliczno-diamentowe na bazie otrzymanych mieszanek (Baza, Baza $+10 \% \mathrm{SiC}, \mathrm{Baza}+10 \% \mathrm{Al}_{2} \mathrm{O}_{3}$ ) i diamentu syntetycznego metalizowanego Ti z gatunku MBS 970 firmy Hyperion Materials \& Technologies o granulacji 30/40 mesh i koncentracji 20 (5\% obj.). Mieszanki proszków osnowy i diamentu przygotowano $\mathrm{w}$ homogenizatorze Speed-Mixer DAC 400.1 FVZ (mieszano przez $10 \mathrm{~min}$ ), po czym poddano je konsolidacji metodą SPS w specjalnie zaprojektowanej matrycy, umożliwiającej jednoczesne spiekanie trzech cylindrycznych próbek o nominalnych wymiarach $\varnothing 11,3 \times 7 \mathrm{~mm}$, w temperaturze $900^{\circ} \mathrm{C}$, przez $10 \mathrm{~min}$, pod ciśnieniem $35 \mathrm{MPa}$.

Otrzymane segmenty poddano pomiarom gęstości metodą ważenia w powietrzu i w wodzie oraz odporności na zużycie ścierne. Pomiar odporności segmentów metaliczno-diamentowych na zużycie ścierne polegał na jednoczesnym przesuwaniu trzech cylindrycznych próbek względem tarczy ścierającej wykonanej z betonu, z zastosowaniem wody jako czynnika chłodzącego i wymywającego ścierne produkty obróbki. Segmenty umieszczano w stalowych obejmach, które mocowano w standardowym uchwycie próbek, znajdującym się na wyposażeniu głowicy RotoForce-4. Podczas każdego 20-sekundowego cyklu pomiarowego segmenty indywidualnie dociskano do kamiennej tarczy ścierającej z siłą $F=20$ N. Prędkość obrotowa tarczy wynosiła $150 \mathrm{obr} / \mathrm{min}$. Po każdym 20-sekundowym cyklu pomiarowym segmenty dokładnie myto w etanolu (w płuczce ultradźwiękowej), a następnie suszono i ważono z dokładnością do 0,1 mg. Po obliczeniu utraty objętości poddawano je obserwacji pod mikroskopem cyfrowym Dino Lite Digital Mikroscope Dremler w powiększeniu 40×, aby określić liczbę kryształów diamentu na roboczej powierzchni segmentu. Schemat pomiaru zużycia segmentów metaliczno-diamentowych w warunkach laboratoryjnych testów eksploatacyjnych oraz stanowisko wykorzystane do badań przedstawiono odpowiednio na rys. 3 i 4.

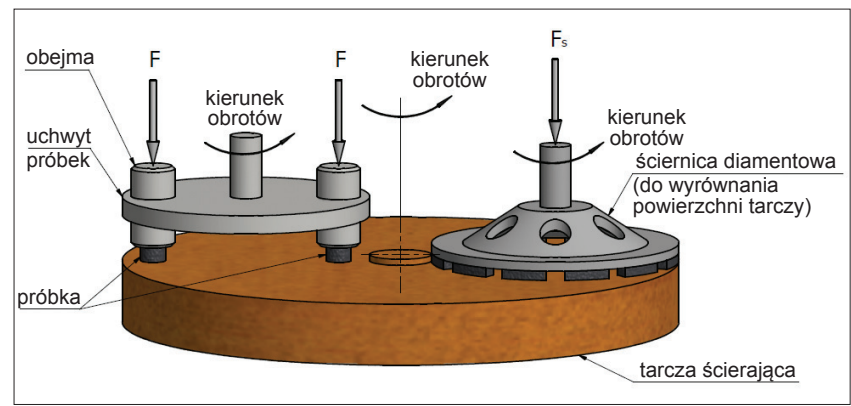

Fig. 3. Schematic representation of the purpose-built rig used to test diamond impregnated specimens in laboratory conditions of operational tests

Rys. 3. Zasada pomiaru zużycia segmentów metaliczno-diamentowych w warunkach laboratoryjnych testów eksploatacyjnych

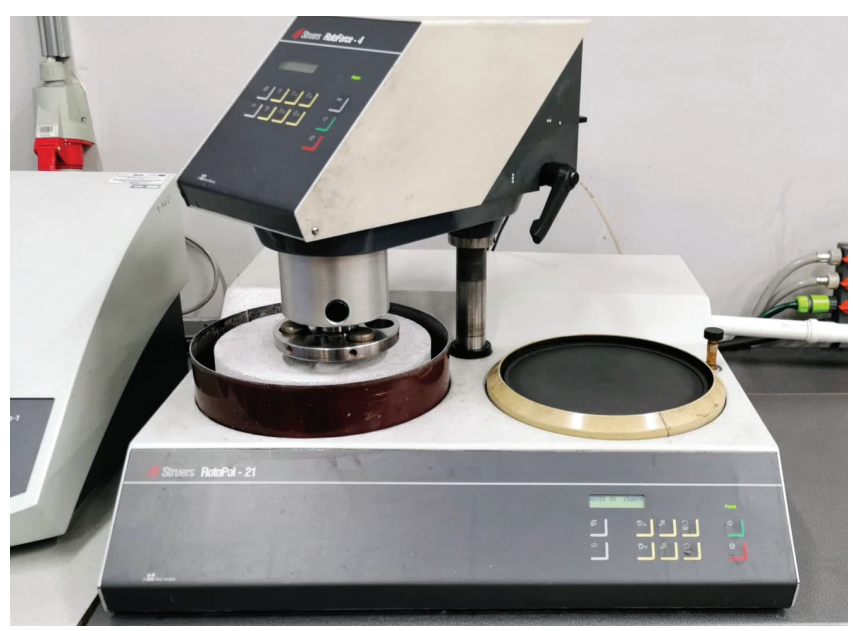

Fig. 4. Stand for testing the wear of metallic-diamond segments Rys. 4. Stanowisko do badań zużycia segmentów metaliczno-diamentowych

\section{Wyniki badań}

W celu ustalenia optymalnych warunków spiekania dla wszystkich badanych materiałów procesy SPS prowadzono w szerokim zakresie temperatury. Wartości gęstości względnej i twardości stanowiły wstępne kryteria oceny stopni konsolidacji spieków otrzymanych metodą SPS. Wyniki przedstawiono na rys. 5.

TABLE. Averaged value of abrasive wear in the presence of two and three sintered bodies obtained by the SPS method at the temperature of $900^{\circ} \mathrm{C}$, during $10 \mathrm{~min}$ and under the pressure of $35 \mathrm{MPa}$

TABLICA. Uśredniona wartość zużycia ściernego w obecności dwóch i trzech ciał spieków otrzymanych metodą SPS w temperaturze $900^{\circ} \mathrm{C}$, w czasie 10 min i pod ciśnieniem $35 \mathrm{MPa}$

\begin{tabular}{|c|c|c|}
\hline \multirow{2}{*}{ Materiał } & \multicolumn{2}{|c|}{ Zużycie $[\mu \mathrm{m} / 20 \mathrm{~m}] \mathrm{w}$ obecności ${ }^{(1)}$} \\
\cline { 2 - 3 } & trzech ciał $\left(\mathrm{Ai}_{3}\right)$ & dwóch ciał $\left(\mathrm{Ai}_{2}\right)$ \\
\hline Baza $(\mathrm{Fe}-\mathrm{Mn}-\mathrm{Cu}-\mathrm{Sn}-\mathrm{C})$ & $24,6 \pm 2,72$ & $138,7 \pm 1,2$ \\
\hline Baza+10\%SiC & $13,6 \pm 2,05$ & $104,9 \pm 10,6$ \\
\hline Baza+10\% & $11,0 \pm 2,27$ & $49,9 \pm 11,7$ \\
\hline
\end{tabular}

(1) Przedziały ufności oszacowano dla poziomu 90\% 


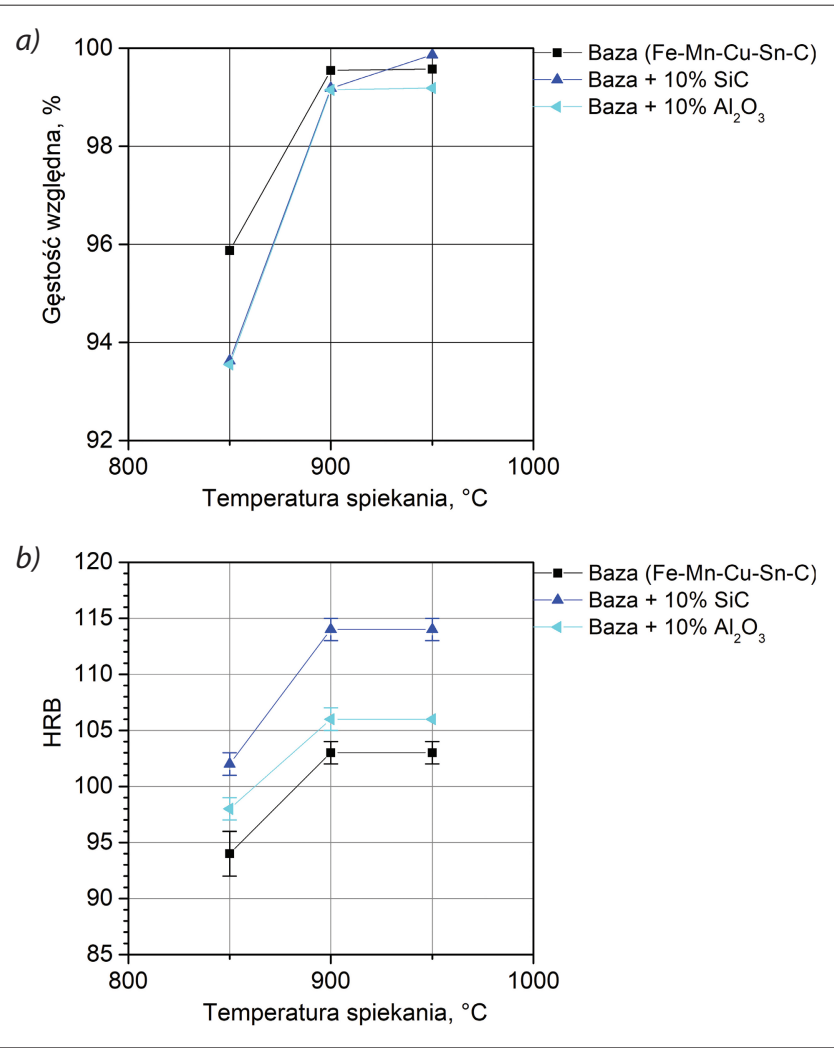

Fig. 5. Relative density $(a)$ and HRB $(b)$ of iron-based composites sintered with SPS in the temperature range of $850 \div 950^{\circ} \mathrm{C}$

Rys. 5. Gęstość względna (a) i HRB (b) kompozytów na osnowie z żelaza spiekanych za pomocą SPS w zakresie temperatury $850 \div 950^{\circ} \mathrm{C}$

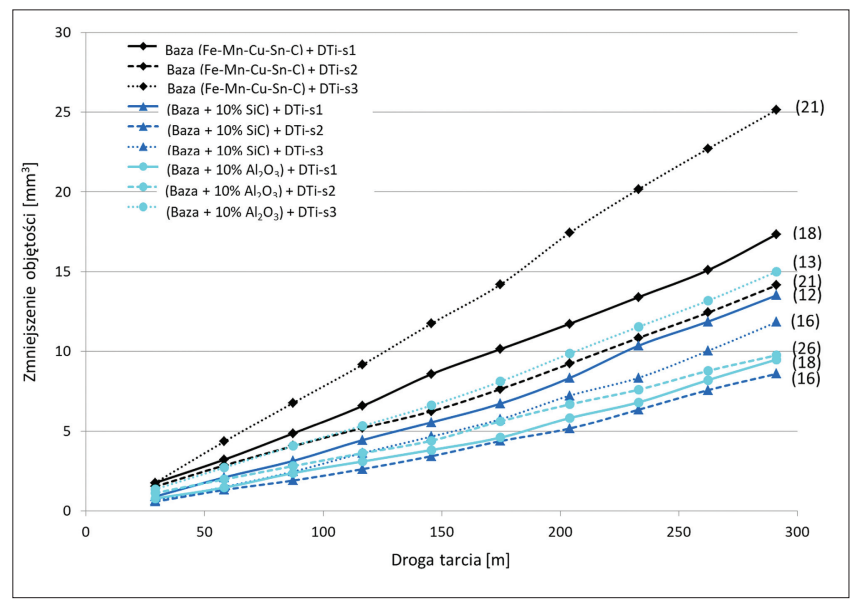

Fig. 6. Reduction of the volume of metallic-diamond segments as a function of the friction path (the average number of diamond crystals on the working surface of the segment after 10 measuring cycles is given in brackets)

Rys. 6. Zmniejszenie objętości segmentów metaliczno-diamentowych w funkcji drogi tarcia ( $w$ nawiasie podano średnią liczbę kryształów diamentu na roboczej powierzchni segmentu po 10 cyklach pomiarowych)

Wyniki badań odporności na zużycie ścierne materiałów stanowiących osnowę i spiekanych segmentów metaliczno-diamentowych przedstawiono odpowiednio w tablicy i na rys. 6.

\section{Analiza wyników}

Przyjęte parametry procesu spiekania umożliwiły uzyskanie spieków o wysokiej gęstości względnej, powyżej 98\% (rys. 5a). Twardość kompozytów osiąga maksimum przy temperaturze $900^{\circ} \mathrm{C}$ (rys. $5 b$ ), dlatego należy uznać, że $\mathrm{w}$ tej temperaturze uzyskano optymalne właściwości fizyko-mechaniczne badanych kompozytów. Badania właściwości tribologicznych wykazały, że kompozyty modyfikowane cząstkami fazy ceramicznej charakteryzują się ponaddwukrotnie wyższą odpornością na zużycie ścierne w porównaniu z materiałami bazowymi (tablica). Badania postępu zużywania się segmentów metaliczno-diamentowych $\mathrm{w}$ procesie szlifowania powierzchni betonowych wskazały na duże znaczenie rodzaju materiału osnowy i jego odporności na zużycie ścierne. Najmniej zużywały się kompozyty zawierające $\mathrm{w}$ materiale osnowy cząstki fazy $\mathrm{Al}_{2} \mathrm{O}_{3}$.

Przedstawiona w pracy technologia wytwarzania segmentów z tanich elementarnych proszków jest uzasadniona ekonomicznie i może być $\mathrm{z}$ powodzeniem stosowana $\mathrm{w}$ procesie produkcji narzędziowych spieków metaliczno-diamentowych przeznaczonych do szlifowania powierzchni betonowych oraz kamiennych.

\section{Wnioski}

Na podstawie badań stwierdzono, że:

- metodą SPS można uzyskać materiały o gęstości zbliżonej do gęstości teoretycznej i wysokiej twardości,

- najlepszym połączeniem właściwości fizycznych i mechanicznych charakteryzowały się materiały spiekane w temperaturze $900^{\circ} \mathrm{C}$, pod ciśnieniem $35 \mathrm{MPa}$ i w czasie $10 \mathrm{~min}$

- wprowadzenie fazy ceramicznej do materiału bazowego Fe-Mn-Cu-Sn-C znacząco wpłynęło na poprawę jego właściwości mechanicznych i tribologicznych,

- badane materiały spełniają kryteria zastosowania ich w produkcji narzędzi diamentowych przeznaczonych do obróbki posadzek betonowych i kamiennych.

Badania były realizowane $w$ ramach projektu LIDER IX, nr umowy: LIDER/22/0085/L-9/17/ NCBR/2018 pt.: Innowacyjne narzędzia metaliczno-diamentowe bez udziału materiałów krytycznych do zastosowań w procesie szlifowania przemysłowych systemów posadzkowych, finansowanego przez Narodowe Centrum Badań i Rozwoju w Warszawie.

\section{LITERATURA}

[1] Clark I.E., Kamphuis B.J. “Cobalite HDR - a new prealloyed matrix powder for diamond construction tools". Ind. Diam. Rev. 62 (2002): 177-182.

[2] Bonneau M., Moltenni M. "Wire manufacturing and free sintering with Next". Ind. Diam. Rev. 4 (2002): 263-265.

[3] "Keen - a new concept in prealloyed powders". Ind. Diam. Rev. 3 (2005): 45-47.

[4] Romański A. „Rozwój materiałów osnowy w narzędziowych spiekach metaliczno-diamentowych". Kraków: Akademia Górniczo-Hutnicza, 2015.

[5] Bonneau M., Moltenni M. "Wire Manufacturing and Free Sintering with NEXT". Ind. Diam. Rev. 4 (2002): 263-265. 
[6] de Oliveira H.C.P., Cabral S.C., Guimarães R.S., Filgueira M. "Mechanical properties of the hot pressed $\mathrm{Cu}-25 \%$ wtFe-25\%wtCo alloy". Diam. Appl. Tecnol. 64 (2011): 20-25.

[7] Kamphuis A., Serneels B. "Sawing and drilling of natural stone and concrete with Cobalite HDR". Proceedings of Euro PM2006 Congress \& Exhibition. Ghent (Belgium) 2006.

[8] Molteni M. "Free sintering pre-alloyed powders: high performance binders as driver of competitiveness". Diam. Appl. Tecnol. 74 (2013): 41-48.

[9] Clark B.J., Kamphuis I.E. "Cobalite HDR - a new prealloyed matrix powder for diamond construction tools". Ind. Diam. Rev. 62, 594 (2002): 177-182.

[10] Romański A., Frydrych H., Konstanty J. „Spieki narzędziowe metaliczno-diamentowe: własności użytkowe a własności materiału osnowy". Rudy i Met. Nieżelazne. 47, 10-11 (2002): 564-569, bwmeta1.element.baztech-article-B0S5-0012-0096.

[11] Konstanty J. „Diamond bonding and matrix wear mechanism involved in circular sawing of stone". Ind. Diam. Rev. 60, 1 (2000): 55-65.

[12] Żak-Szwed M. "Kształtowanie mikrostruktury i właściwości spieków żelazo-miedź przeznaczonych na osnowe materiałów metaliczno-diamentowych". Kraków: AGH, 2009.

[13] Żak-Szwed M., Konstanty J., Radziszewska A. „Własności spieków $\{\mathrm{Fe}-\mathrm{Cu}\}$ i $\{\mathrm{Fe}-\mathrm{Cu}-\mathrm{Sn}\}$ spełniających rolę osnowy w narzędziach metaliczno-diamentowych". Hut. Wiadomości Hut. 75, 4 (2008): 186-192, bwmeta1.element.baztech-article-BPLA-0013-0029.

[14] Żak-Szwed M., Konstanty J., Zielińska-Lipiec A. "Iron-base PM matrix alloys for diamond-impregnated tools". Int. J. Powder Metall. 45, 3 (2009): 36.

[15] Żak-Szwed M., Konstanty J. „Wpływ warunków wytwarzania na własności spieków $\{\mathrm{Fe}-50$ \%Co\}". Inżynieria Mater. 29, 1 (2008): 21-26, bwmeta1.element.baztech-article-BPL8-0006-0003.

[16] Żak-Szwed M., Konstanty J., Ratuszek W. "Properties of $\{\mathrm{Fe}-\mathrm{Cu}\}$ matrices for diamond impregnated tools". Ind. Diam. Rev. 2 (2008): 29-34.

[17] Spriano S., Chen Q., Settineri L., Bugliosi S. "Low content and free cobalt matrixes for diamond tools". Wear. 259, 7-12 (2005): 1190-1196, https://doi.org/10.1016/ j.wear.2005.02.076

[18] Hamar-Thibault S., Allibert C.H. "New phases in the ternary Cu-Ti-Sn system". J. Alloys Compd. 317-318 (2001): 363366, https://doi.org/10.1016/S0925-8388(00)01439-0.

[19] Ching-Shan Lin, Yue-Lin Yang, Shun-Tian Lin. "Performances of metal-bond diamond tools in grinding alumina". J. Mater. Process. Technol. 201, 1-3 (2008): 612-617, https://doi.org/10.1016/j.jmatprotec.2007.11.141.

[20] de Oliveira L.J., Bobrovnitchii G.S., Filgueira M. "Processing and characterization of impregnated diamond cutting tools using a ferrous metal matrix". Int. J. Refract. Met. Hard Mater. 25, 4 (2007): 328-335, https://doi.org/10.1016/ j.ijrmhm.2006.08.006.

[21] Bączek E., Konstanty J., Romański A., Podsiadło M., Cyboroń J. "Processing and Characterization of Fe-Mn-Cu-Sn-C Alloys Prepared by Ball Milling and Spark Plasma Sintering". Journal of Materials Engineering and Performance. 29 (2018): 1-9, https://doi.org/10.1007/s11665-0183181-5.

[22] Konstanty J., Bączek E., Romański A., Tyrała D. “Wear-resistant iron-based Mn-Cu-Sn matrix for sintered diamond tools". Powder Metallurgy. (2017): 1-7, https://doi.org/ 10.1080/00325899.2017.1379737.

[23] Micro Wear Test - Instruction Manual. Denmark: Struers Tech., 1989

[24] Konstanty J. Testing resistance to abrasive wear of iron-base materials used as metallic matrices in diamond impregnated tool components. Final Report, February 2007. Praca niepublikowana, wykonana na zlecenie EHWA Diamond Ind. Co Ltd. Osan (Korea Południowa), 2007. 